\title{
NOTE
}

\section{Effects of ocean acidification on overwintering juvenile Arctic pteropods Limacina helicina}

\author{
S. Comeau ${ }^{1,2,3, *}$, S. Alliouane ${ }^{1,2}$, J.-P. Gattuso ${ }^{1,2}$ \\ ${ }^{1}$ Centre National de la Recherche Scientifique-Institut National des Sciences de l'Univers (CNRS-INSU), \\ Laboratoire d'Océanographie de Villefranche, BP 28, 06234 Villefranche-sur-Mer Cedex, France \\ ${ }^{2}$ Université Pierre et Marie Curie-Paris 6, Observatoire Océanologique de Villefranche, 06230 Villefranche-sur-Mer, France \\ ${ }^{3}$ Present address: Department of Biology, California State University, 18111 Nordhoff Street, Northridge, \\ California 91330-8303, USA
}

\begin{abstract}
Pteropods are planktonic mollusks that play an important role in the food web of various ecosystems, particularly at high latitudes. Because they produce an aragonitic shell, pteropods are expected to be very sensitive to ocean acidification driven by anthropogenic $\mathrm{CO}_{2}$ emissions. The effect of ocean acidification was investigated using juveniles of the Arctic pteropod Limacina helicina from the Canada Basin of the Arctic Ocean. The animals were maintained in 3 controlled $\mathrm{pH}$ conditions (total scale $\mathrm{pH}\left[\mathrm{pH}_{\mathrm{T}}\right] \approx 8.05,7.90$ or 7.75 ) for $8 \mathrm{~d}$, and their mortality and the linear extension of their shell were monitored. The $\mathrm{pH}$ did not impact the mortality rate, but the linear extension of the shell decreased as a function of declining $\mathrm{pH}$. Surprisingly, the pteropods were still able to extend their shell at an aragonite saturation state as low as 0.6. Nevertheless, dissolution marks were visible on the whole shell, indicating that calcium carbonate dissolution had also occurred, casting doubts on the ability of the pteropods to maintain a positive balance between precipitation and dissolution of calcium carbonate under corrosive conditions.
\end{abstract}

KEY WORDS: Ocean acidification $\cdot$ Arctic $\cdot$ Pteropod $\cdot$ Shell growth

\section{INTRODUCTION}

Pteropods are pelagic mollusks that play an important role in the food web of extensive oceanic regions, particularly at high latitudes, where they are a major dietary component for zooplankton and higher predators, such as herring, salmon, whales and birds (Hunt et al. 2008). They have an aragonitic shell that acts as ballast, facilitating vertical migration, and protection against their environment (Lalli \& Gilmer 1989). Pteropods are also involved in biogeochemical cycles, to which they are important contributors to the export of calcium carbonate and carbon to the deep ocean (e.g. Honjo 2004, Gangstø et al. 2008).
Pteropods are a current subject of concern due to their sensitivity to ocean acidification, caused by the dissolution of one-fourth of anthropogenic $\mathrm{CO}_{2}$ emissions into the oceans. This uptake limited the increase in the concentration of atmospheric $\mathrm{CO}_{2}$ by $55 \mathrm{ppm}$ (Sabine et al. 2004). However, when $\mathrm{CO}_{2}$ dissolves in seawater, it reacts with $\mathrm{H}_{2} \mathrm{O}$ to form carbonic acid and reduces the $\mathrm{pH}$ of the ocean. Since pre-industrial time, the surface ocean $\mathrm{pH}$ has declined by 0.1 unit, and a further decline of 0.3 to 0.4 units is expected by the end of the century (Orr 2011). Among other changes, declining $\mathrm{pH}$ also causes a decrease in the level of carbonate ions $\left(\mathrm{CO}_{3}{ }^{2-}\right)$ and its associated calcium carbonate saturation state $(\Omega)$. Studies have mainly demonstrated the 
deleterious effect of ocean acidification on many calcifiers, such as coccolithophores (e.g. Riebesell et al. 2000), corals and coralline algae (e.g. Anthony et al. 2008, Martin \& Gattuso 2009) and mollusks (e.g. Michaelidis et al. 2005, Gazeau et al. 2010). However, some studies reported contradictory results, such as no effects or positive effects of ocean acidification on several calcifiers (e.g. Iglesias-Rodriguez et al. 2008, Ries et al. 2009). The possible causes and consequences of such contradictory results were recently examined by Gattuso \& Riebesell (2011).

Experiments carried out in Spitsbergen show a negative impact of ocean acidification on the calcification of both adults (Comeau et al. 2009, 2010a) and early juveniles of Limacina helicina (Lischka et al. 2011). Negative effects of $\mathrm{CO}_{2}$ on juveniles of Mediterranean Cavolinia inflexa (Comeau et al. 2010b) and the Antarctic pteropod Clio pyramidata (Orr et al. 2005) have also been reported. The Arctic pteropod L. helicina is particularly vulnerable to the threat of ocean acidification because the Arctic Ocean is expected to be among the first regions that will exhibit large areas corrosive to calcium carbonate. Models project that undersaturation with respect to aragonite, the crystal form of $\mathrm{CaCO}_{3}$ used by pteropods to build their shell, is going to occur as early as 2016 for 1 mo per year in $10 \%$ of the Arctic surface waters (Steinacher et al. 2009). Furthermore, aragonite undersaturation has already been detected in the Canada Basin of the Arctic Ocean in 2008 (Yamamoto-Kawai et al. 2009).

Our study aims to investigate the impact of ocean acidification on the early life stage of Limacina helicina from the Canada Basin of the Arctic Ocean. The present experiment, performed as a part of the Catlin Arctic Survey, was conducted at the end of winter on organisms collected below the ice floe. These unique spatial and temporal locations were used to better assess the effect of ocean acidification on organisms already submitted to natural unfavorable conditions. Mortality and shell linear extension responses to 3 controlled $\mathrm{pH}$ conditions (total scale $\mathrm{pH}\left[\mathrm{pH}_{\mathrm{T}}\right] \sim 8.05$, 7.90 and 7.75) were investigated.

\section{MATERIALS AND METHODS}

This study was carried out as part of the Catlin Arctic Survey, which is designed to provide insight into the rate, causes and potential worldwide impacts of the disappearance of the Arctic sea ice cover. Sampling and experiments were undertaken in April 2010 in the Canadian Arctic from the Catlin Arctic Survey Ice Base located at $78.72^{\circ} \mathrm{N}, 104.79^{\circ} \mathrm{W}$ in
Deer Bay. The ice base was situated on a region of flat, first year sea ice that was between 1.5 and $1.7 \mathrm{~m}$ thick. Pteropods were collected from an ice hole located $2 \mathrm{~km}$ west of the ice base where the bottom depth was about $350 \mathrm{~m}$. Sampling was performed using a plankton net (modified WP2 net with a $57 \mathrm{~cm}$ mouth diameter, $200 \mu \mathrm{m}$ mesh size and a custommade 101 collector) that was gently trawled vertically from $200 \mathrm{~m}$ to the surface. Additional tows were performed from $100 \mathrm{~m}$ to the surface but only few organisms were collected. After collection, the organisms were maintained in iceboxes to avoid freezing and transported to the ice base. The organisms were selected under a microscope, and the few individuals exhibiting shell damage were eliminated. The nontoxic fluorochrome calcein was used as a growth marker to monitor the linear extension of the shell (e.g. Kaehler \& McQuaid 1999). Before incubation, the shells of 198 pteropods were stained in a calcein fluorochrome bath for $1 \mathrm{~h}$ (final concentration: $50 \mathrm{mg} \mathrm{l}^{-1}$ ) and were then rinsed by successive transfers in unstained seawater to remove the calcein that was not incorporated in the shell. The organisms were then divided among nine $125 \mathrm{ml}$ incubation bottles ( 22 ind. per bottle) containing seawater (collected at $5 \mathrm{~m}$ depth) adjusted to one of $3 \mathrm{pH}$ values through additions of $0.1 \mathrm{~N} \mathrm{HCl}$ (Merck). We are aware that gas bubbling and the addition of acid and bicarbonate and/or carbonate are the methods that best mimic anthropogenic ocean acidification, although acid addition generates changes in the $\mathrm{pH}$, partial pressure of $\mathrm{CO}_{2}\left(\mathrm{pCO}_{2}\right)$ and $\mathrm{CaCO}_{3}$ saturation state in the same direction as the changes generated by gas bubbling (Gattuso et al. 2010). The dire logistic and technical constraints in the ice base and tent laboratory prevented the use of equipment such as a balance, $\mathrm{CO}_{2}$ cylinders or gas mixing pumps. The target $\mathrm{pH}$ values included a control treatment $\left(\mathrm{pH}_{\mathrm{T}}\right.$ 8.05, $\left.\mathrm{pCO}_{2} \sim 380 \mu \mathrm{atm}\right)$, a low $\mathrm{pH}$ treatment corresponding to the $\mathrm{pCO}_{2}$ expected by $2050\left(\mathrm{pH}_{\mathrm{T}} \sim 7.90\right.$; $\left.\mathrm{pCO}_{2} \sim 550 \mu \mathrm{atm}\right)$ and a very low $\mathrm{pH}$ treatment corresponding to the $\mathrm{pCO}_{2}$ expected by the end of the century $\left(\mathrm{pH}_{\mathrm{T}} \sim 7.75 ; \mathrm{pCO}_{2} \sim 760 \mu \mathrm{atm}\right)$. Seawater $\mathrm{pH}$ was measured in the experimental bottles at the beginning and at the end of the incubation using a $\mathrm{pH}$ meter (826 pH mobile, Metrohm) fitted with a glass electrode (Metrohm, electrode plus) calibrated on the total scale using Tris/ $\mathrm{HCl}$ and 2-aminopyridine/ $\mathrm{HCl}$ buffer solutions with a salinity of 33.0 (Dickson et al. 2007). Seawater samples for total alkalinity $\left(A_{\mathrm{T}}\right)$ determination were taken before and after incubation and poisoned with $\mathrm{HgCl}_{2}$, and $A_{\mathrm{T}}$ was measured at the Laboratoire d'Océanographie de 
Villefranche using potentiometric titrations with a Metrohm titrator (titrando 80) according to Dickson et al. (2007). Field samples were also collected to measure $A_{\mathrm{T}}$ and total dissolved inorganic carbon $\left(\mathrm{DIC}_{\mathrm{T}}\right)$. Samples were also poisoned with $\mathrm{HgCl}_{2}$ and stored pending measurement at the Institute of Ocean Sciences (British Columbia, Canada). Parameters of the carbon chemistry were determined from $\mathrm{pH}_{\mathrm{T}}, A_{\mathrm{T}}$ and/or $\mathrm{DIC}_{\mathrm{T}}$, temperature and salinity using the R package seacarb (Lavigne \& Gattuso 2011). The incubation bottles were enriched with $5 \mathrm{ml}$ (equivalent to $1 \mathrm{~m}^{3}$ of the water column) of a solution of phytoplankton and particles collected in the field using a $20 \mu \mathrm{m}$ plankton net lifted from a depth of 100 $\mathrm{m}$ to the surface. The bottles were incubated in seawater through an ice hole to maintain the temperature at the ambient level (ca. $-1.6^{\circ} \mathrm{C}$ ). Upon completion of the incubation $(8 \mathrm{~d})$, the active individuals were separated from the dead ones, which were discarded. Half of the active individuals were stored frozen but were damaged during the process and were not used for shell linear extension measurements. The other half was stored in a buffered formalin solution for subsequent measurement of linear extension. Photographs of the organisms were made at the Laboratoire d'Océanographie de Villefranche under UV-epifluorescence using a Zeiss Axiovert 25 microscope. The shell extension and shell diameter were measured on photographs using the software ImageJ (US National Institutes of Health). Shell extension corresponds to the linear growth of the shell during the $8 \mathrm{~d}$ following calcein staining (for details, see Comeau et al. 2009). To take into account differences in individual sizes, the ratio between shell extension and shell diameter was calculated.
Because the data were not normally distributed, a non-parametric Wilcoxon test was used to compare the 3 treatments by pairs.

\section{RESULTS}

The aragonite saturation state $\left(\Omega_{\mathrm{a}}\right)$ in the field was particularly low, with a maximum $\Omega_{\mathrm{a}}$ of 1.4 at $10 \mathrm{~m}$ (Table 1). $\Omega_{\mathrm{a}}$ tends to decrease with increasing depth until $100 \mathrm{~m}$, where it exhibits a minimum of $1.07 . \Omega_{\mathrm{a}}$ was $\sim 1.21$ at $200 \mathrm{~m}$, the maximum depth of pteropod collection. In the incubation bottles, $\Omega_{\mathrm{a}}$ was also particularly low: the mean $\Omega_{\mathrm{a}}$ over the incubation period was $\sim 1.13$ in the control treatment. In the other treatments, seawater was undersaturated with respect to aragonite, with mean $\Omega_{\mathrm{a}}$ values of 0.79 and 0.59 in the low and very low $\mathrm{pH}$ treatments respectively (Table 1).

The incubated organisms suffered mortalities of 6 , 8 and $9 \%$ in the control, low and very low pH treatments respectively. The organisms were of similar sizes in the 3 treatments, with a mean $( \pm \mathrm{SD})$ maximum diameter of the shell of $1773 \pm 230 \mu \mathrm{m}$. After $8 \mathrm{~d}$ of incubation, the ratio of linear extension $(L E)$ to shell diameter $(D)$ was $0.34 \pm 0.1,0.21 \pm 0.1$ and $0.17 \pm 0.1 \mu \mathrm{m}(L E) \mu^{-1}(D)$ in the control, low and very low $\mathrm{pH}$ treatments respectively (Fig. 1). Wilcoxon tests revealed a significant difference $(p<0.01)$ in linear extension between pteropods maintained in the control treatment and those maintained at low and very low $\mathrm{pH}$ treatments, whereas there was no significant difference in the $L E: D$ ratio between organisms maintained at low and very low $\mathrm{pH}$ treatments $(p=0.078)$. The shells of the juveniles main-

Table 1. Parameters of the carbonate chemistry in the 3 experimental conditions (control, low $\mathrm{pH}$, very low $\mathrm{pH}$ ) and in the field at 5,10, 100 and $200 \mathrm{~m}$ depth. Mean $\pm \mathrm{SD}$ is shown for the parameters that were measured $(\mathrm{n}=6$ for $\mathrm{pH}$, and $\mathrm{n}=9 \mathrm{for}$ total alkalinity $\left[A_{\mathrm{T}}\right]$ and total dissolved inorganic carbon $\left.\left[\mathrm{DIC}_{\mathrm{T}}\right]\right)$. Total $\mathrm{pH}\left(\mathrm{pH}_{\mathrm{T}}\right)$ is the average of the mean pH values measured in the incubation bottles at the start $\left(t_{0}\right)$ and end $\left(t_{\mathrm{f}}\right)$ of the incubation; for the field measurements it is calculated from DIC ${ }_{\mathrm{T}}, A_{\mathrm{T}}$, salinity and temperature. $A_{\mathrm{T}}$ is the average of the mean total alkalinity measured in the incubation bottles at the start $\left(t_{0}\right)$ and end $\left(t_{\mathrm{f}}\right)$ of the incubation; for the field measurements it is the measured values. The concentration of DIC $\mathrm{T}$, partial pressure of $\mathrm{CO}_{2}\left(\mathrm{pCO}_{2}\right)$ and saturation state of aragonite $\left(\Omega_{\mathrm{a}}\right)$ were derived from $\mathrm{pH}_{\mathrm{T}}, A_{\mathrm{T}}$, salinity and temperature in the experimental bottles and from $\mathrm{DIC}_{\mathrm{T}}, A_{\mathrm{T}}$, salinity and temperature for field measurements

\begin{tabular}{|c|c|c|c|c|c|c|c|c|c|c|c|}
\hline Conditions & $t_{0}^{p}$ & $\mathrm{H}_{\mathrm{T}}$ & $\begin{array}{l}A_{\mathrm{T}}(\mu \mathrm{m} \\
\quad t_{0}\end{array}$ & $\begin{array}{l}\text { ol } \mathrm{kg}^{-1} \text { ) } \\
t_{\mathrm{f}}\end{array}$ & $\mathrm{pH}_{\mathrm{T}}$ & 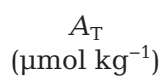 & $\begin{array}{c}\mathrm{DIC}_{\mathrm{T}} \\
\left(\mu \mathrm{mol} \mathrm{kg}{ }^{-1}\right)\end{array}$ & $\begin{array}{l}\mathrm{pCO}_{2} \\
(\mu \mathrm{atm})\end{array}$ & $\begin{array}{c}\mathrm{HCO}_{3}^{-} \\
\left(\mu \mathrm{mol} \mathrm{kg}{ }^{-1}\right)\end{array}$ & $\begin{array}{c}\mathrm{CO}_{3}{ }^{2-} \\
\left(\mu \mathrm{mol} \mathrm{kg}{ }^{-1}\right)\end{array}$ & $\Omega_{\mathrm{a}}$ \\
\hline Control & 8.07 & 8.03 & 2143 & 2132 & $8.05 \pm 0.03$ & $2137 \pm 8$ & 2048 & 362 & 1949 & 74 & 1.13 \\
\hline Low pH & 7.92 & 7.86 & 2102 & 2106 & $7.89 \pm 0.04$ & $2104 \pm 3$ & 2060 & 530 & 1971 & 52 & 0.79 \\
\hline Very low pH & 7.78 & 7.74 & 2052 & 2065 & $7.76 \pm 0.03$ & $2058 \pm 11$ & 2046 & 704 & 1959 & 39 & 0.59 \\
\hline Field $5 \mathrm{~m}$ & - & - & - & - & 8.14 & $2143 \pm 7$ & $2024 \pm 5$ & 287 & 1913 & 91 & 1.39 \\
\hline Field $10 \mathrm{~m}$ & - & - & - & - & 8.14 & $2144 \pm 5$ & $2023 \pm 2$ & 285 & 1912 & 92 & 1.40 \\
\hline Field $100 \mathrm{~m}$ & - & - & - & - & 7.96 & $2264 \pm 2$ & $2185 \pm 3$ & 459 & 2083 & 72 & 1.07 \\
\hline Field $200 \mathrm{~m}$ & - & - & - & - & 7.99 & $2301 \pm 2$ & $2202 \pm 4$ & 430 & 2092 & 83 & 1.21 \\
\hline
\end{tabular}




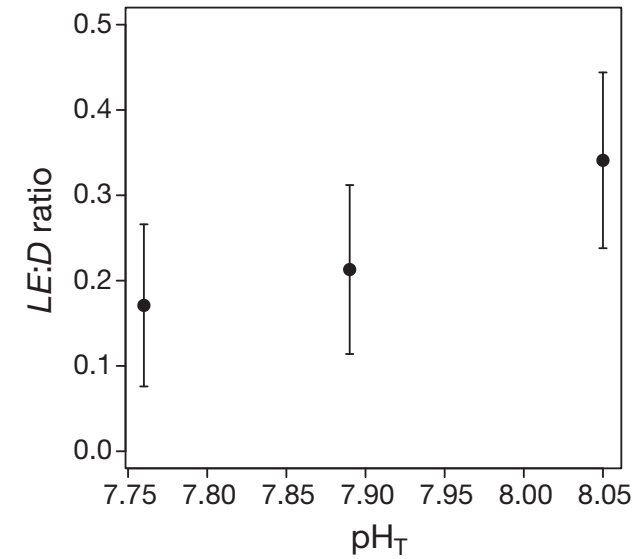

Fig. 1. Limacina helicina. Mean $\pm \mathrm{SD}$ ratio of the shell linear extension $(L E)$ and shell diameter $(D)$ of juveniles after $8 \mathrm{~d}$ of incubation in control (total $\left.\mathrm{pH}\left[\mathrm{pH}_{\mathrm{T}}\right] \sim 8.05\right)$, low $\mathrm{pH}\left(\mathrm{pH}_{\mathrm{T}}\right.$ $\sim 7.89)$ and very low $\mathrm{pH}\left(\mathrm{pH}_{\mathrm{T}} \sim 7.76\right)$ treatments. The ratio was significantly different $(\mathrm{p}<0.01)$ between control and both low $\mathrm{pH}$ and very low $\mathrm{pH}$ treatments. There was no significant difference between the low and very low $\mathrm{pH}$ treatments $(p=0.078)$

tained at the control $\mathrm{pH}$ were not altered during the incubation (Fig. 2a). In contrast, dissolution marks were visible on the shells of the organisms maintained at low pH (Fig. 2b), and large dissolution marks as well as cracks were present on the shell of pteropods maintained at very low $\mathrm{pH}$ (Fig. 2c).

\section{DISCUSSION}

The individuals of Limacina helicina investigated were collected in waters with a low $\Omega_{\mathrm{a}}$. Most of them were sampled at depths ranging between 100 and $200 \mathrm{~m}$, where the saturation state is close to the threshold between supersaturation and undersatura- tion with respect to aragonite $\left(\Omega_{\mathrm{a}} \sim 1.0\right)$. The low saturation state of the Canada Basin has already been observed in 2008 by Yamamoto-Kawai et al. (2009). Those authors suggested that characteristics of the water masses, such as low salinity due to sea ice melt water and high organic matter re-mineralization in the layer between 100 and $200 \mathrm{~m}$, explain the low saturation of these waters. This is in agreement with the higher concentrations of $\mathrm{DIC}_{\mathrm{T}}$ that we measured at 100 and $200 \mathrm{~m}$ depth $\left(\mathrm{DIC}_{\mathrm{T}} \sim 2200 \mu \mathrm{mol} \mathrm{kg}{ }^{-1}\right)$ than at 5 and $\left.10 \mathrm{~m} \mathrm{( \textrm {DIC } _ { \mathrm { T } } \sim 2 0 2 0 \mu \mathrm { mol } \mathrm { kg }}{ }^{-1}\right)$.

To date, published studies on the impact of ocean acidification on Arctic pteropods have only been carried out in Svalbard (Comeau et al. 2009, 2010a, Lischka et al. 2011), at a latitude similar to the one of our study site $\left(\sim 79^{\circ} \mathrm{N}\right)$, but in a region with higher saturation states. For example, Comeau et al. (2010a) reported that the $\Omega_{\mathrm{a}}$ at the surface in a fjord west of Spitsbergen was $\sim 2$. Physico-chemical properties, such as the influence of Atlantic water (Cottier et al. 2005) with high total alkalinity and higher temperature in the Greenland Sea, explain the lower sensitivity of western Svalbard waters to ocean acidification.

To our knowledge, the present study is the first one conducted in early spring conditions using late overwintering organisms. Despite $\sim 24 \mathrm{~h}$ of sunlight, the phytoplankton concentration was still very low under the ice floe. A reduced food supply beginning the previous summer might increase the sensitivity of pteropods to physical stress at this time of the year. However, the results demonstrate that, despite relatively harsh conditions, juveniles were able to extend their shell even in corrosive waters. Pteropods are accustomed to being exposed to a low aragonite saturation state, particularly when they are overwintering in the deeper layer of the water column, and may, therefore, be able to calcify at a low $\Omega_{\mathrm{a}}$. The physiol-
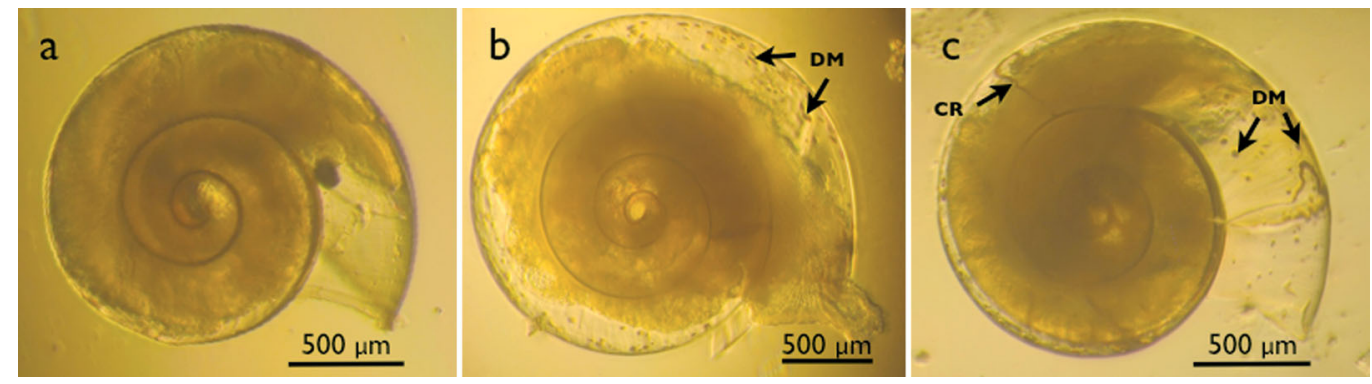

Fig. 2. Limacina helicina. Impact of seawater carbonate chemistry on the shell of juveniles maintained at $3 \mathrm{pH}$ conditions for $8 \mathrm{~d}$. Photographs were taken of organisms stored in a buffered formalin solution. Pteropods were able to extend their shell in the $3 \mathrm{pH}$ conditions. Nevertheless, the shells of pteropods maintained at (a) control conditions (total $\left.\mathrm{pH}\left[\mathrm{pH}_{\mathrm{T}}\right] \sim 8.05\right)$ were intact, whereas the shells exhibited dissolution marks (DM) at (b) low $\mathrm{pH}\left(\mathrm{pH}_{\mathrm{T}} \sim 7.89\right)$ and extensive $\mathrm{DM}$ and cracks $(\mathrm{CR})$ at (c) very low $\mathrm{pH}\left(\mathrm{pH}_{\mathrm{T}} \sim 7.76\right)$ 
ogy of calcification remains unknown in pteropods, but our data demonstrate that they are able to elevate $\Omega_{\mathrm{a}}$ from seawater values as low as 0.6 to values $>1$ at the site of calcification. The presence of a thin periostracal layer covering the calcareous surface, as shown on the Antarctic pteropod Limacina helicina antarctica (Sato-Okoshi et al. 2010), might, among other mechanisms, protect the shell from a corrosive environment. Enzymatic reactions, such as the one involving carbonic anhydrase (e.g. Freeman \& Wilbur 1948), an enzyme that catalyses the reversible hydration of $\mathrm{CO}_{2}$ to $\mathrm{HCO}_{3}^{-}$and $\mathrm{H}^{+}$, might also be involved in the ability of pteropods to calcify in undersaturated waters. However, its presence and activity have not been demonstrated in pteropods to date.

Lischka et al. (2011) have also shown that larvae of Limacina helicina collected in Svalbard exhibited a positive linear extension of their shell after incubation in seawater undersaturated with respect to aragonite. Positive gross calcification in slightly undersaturated waters, measured using ${ }^{45} \mathrm{Ca}$ uptake, has also been reported on adults of $L$. helicina collected in Svalbard (Comeau et al. 2009, 2010a).

In the present study, only the linear extension of the shell was investigated. It must be pointed out that linear extension does not provide any information on the calcification rate because extension also depends on the density or thickness of the newly formed shell. The alkalinity anomaly technique was used to estimate the rate of net calcification, but the changes in total alkalinity were below the detection limit. Hence, even though our results demonstrate that pteropods are able to produce shell in corrosive waters, the results do not provide information on the balance between the precipitation and dissolution of $\mathrm{CaCO}_{3}$. In corrosive waters, the whole pteropod shell is likely affected by dissolution, whereas calcification mostly occurs at the edge of the shell aperture. This is confirmed by the extensive dissolution marks on organisms maintained in undersaturated waters (Fig. 2b,c). Dissolution of the shell has also been observed in the Antarctic pteropod Clio pyramidata maintained in undersaturated waters with respect to aragonite (Orr et al. 2005) and in larvae of the Mediterranean species Cavolinia inflexa grown in seawater corrosive to aragonite (Comeau et al. 2010b). Model projections suggest that undersaturation of surface water with respect to aragonite will occur as early as 2016 for 1 mo per year in $10 \%$ of the Arctic Ocean (Steinacher et al. 2009). Subsurface waters are also affected by ocean acidification as models project that the aragonite saturation horizon (the limit between undersaturation and supersaturation) will rise towards the surface substantially throughout the oceans (Orr et al. 2005). It is uncertain whether or how long pteropods will be able to maintain a positive balance between precipitation and dissolution of calcium carbonate.

Acknowledgements. Thanks to the Catlin Arctic Survey team and Geo Mission for their support in the field and to O. Wurl and H. Findlay for helpful field assistance. L. Miller and her group are gratefully acknowledged for analyzing the concentrations of dissolved inorganic carbon and total alkalinity. Thanks are also due to the anonymous referees for useful comments on an earlier version of this paper. This study draws on the analysis of data secured from fieldwork undertaken as part of the Catlin Arctic Survey, made possible by the funding support of the Catlin Group. This work is a contribution to the 'European Project on Ocean Acidification' (EPOCA), which received funding from the European Community's Seventh Framework Program (FP7/2007-2013) under grant agreement no. 211384.

\section{LITERATURE CITED}

Anthony KRN, Kline DI, Diaz-Pulido G, Dove S, HoeghGuldberg O (2008) Ocean acidification causes bleaching and productivity loss in coral reef builders. Proc Natl Acad Sci USA 105:17442-17446

> Comeau S, Gorsky G, Jeffree R, Teyssié JL, Gattuso JP (2009) Impact of ocean acidification on a key Arctic pelagic mollusc (Limacina helicina). Biogeosciences 6: $1877-1882$

> Comeau S, Jeffree R, Teyssié JL, Gattuso JP (2010a) Response of the Arctic pteropod Limacina helicina to projected future environmental conditions. PLoS ONE 5: e11362

Comeau S, Gorsky G, Alliouane S, Gattuso JP (2010b) Larvae of the pteropod Cavolinia inflexa exposed to aragonite undersaturation are viable but shell-less. Mar Biol 157:2341-2345

Cottier F, Tverberg V, Inall M, Svendsen H, Nilsen F, Griffiths C (2005) Water mass modification in an Arctic fjord through cross-shelf exchange: the seasonal hydrography of Kongsfjorden, Svalbard. J Geophys Res 110:C12005 doi:10.1029/2004JC002757

Dickson AG, Sabine CL, Christian JR (eds) (2007) Guide to best practices for $\mathrm{CO}_{2}$ measurements. PICES Special Publication 3, PICES, Sidney, BC

- Freeman JA, Wilbur KM (1948) Carbonic anhydrase in molluscs. Biol Bull 94:55-59

> Gangstø R, Gehlen M, Schneider B, Bopp L, Aumont O, Joos F (2008) Modeling the marine aragonite cycle: changes under rising carbon dioxide and its role in shallow water $\mathrm{CaCO}_{3}$ dissolution. Biogeosciences 5:1057-1072

Gattuso JP, Riebesell U (2011) Reconciling apparently contradictory observations. In: Field CB, Barros V, Stocker TF, Qin D and others (eds) Workshop report of the Intergovernmental Panel on Climate Change workshop on impacts of ocean acidification on marine biology and ecosystems. IPCC Working Group II Technical Support Unit, Carnegie Institution, Stanford, CA, p 10-16 
Gattuso JP, Gao K, Lee K, Rost B, Schulz KG (2010) Approaches and tools to manipulate the carbonate chemistry. In: Riebesell U, Fabry VJ, Hansson L, Gattuso JP (eds) Guide to best practices for ocean acidification research and data reporting. Publications Office of the European Union, Luxembourg, p 243-258

Gazeau F, Gattuso JP, Dawber C, Pronker AE and others (2010) Effect of ocean acidification on the early life stages of the blue mussel Mytilus edulis. Biogeosciences 7:2051-2060

Honjo S (2004) Particle export and the biological pump in the Southern Ocean. Antarct Sci 16:501-516

Hunt B, Pakhomov E, Hosie G, Siegel V, Ward P, Bernard K (2008) Pteropods in Southern Ocean ecosystems. Prog Oceanogr 78:193-221

Iglesias-Rodriguez MD, Halloran PR, Rickaby REM, Hall IR and others (2008) Phytoplankton calcification in a high$\mathrm{CO}_{2}$ world. Science 320:336-340

Kaehler S, McQuaid CD (1999) Use of the fluorochrome calcein as an in situ growth marker in the brown mussel Perna perna. Mar Biol 133:455-460

Lalli CM, Gilmer RW (1989) Pelagic snails. The biology of holoplanktonic gastropod mollusks. Stanford University Press, Stanford, CA

Lavigne H, Gattuso JP (2011) seacarb: seawater carbonate chemistry with R. R package version 2.4.1 http://CRAN. Rproject.org/package=seacarb

Lischka S, Büdenbender J, Boxhammer T, Riebesell U (2011) Impact of ocean acidification and elevated temperatures on early juveniles of the polar shelled pteropod Limacina helicina: mortality, shell degradation, and shell growth. Biogeosciences 8:919-932

Martin S, Gattuso JP (2009) Response of Mediterranean coralline algae to ocean acidification and elevated tem-

Editorial responsibility: Gretchen Hofmann, Santa Barbara, California, USA perature. Glob Change Biol 15:2089-2100

> Michaelidis B, Ouzounis C, Paleras A, Pörtner HO (2005) Effects of long-term moderate hypercapnia on acidbase balance and growth rate in marine mussels Mytilus galloprovincialis. Mar Ecol Prog Ser 293: $109-118$

Orr JC (2011) Recent and future changes in ocean carbonate chemistry. In: Gattuso JP, Hansson L (eds) Ocean acidification. Oxford University Press, Oxford, p 41-66

> Orr JC, Fabry VJ, Aumont O, Bopp L and others (2005) Anthropogenic ocean acidification over the twenty-first century and its impact on calcifying organisms. Nature 437:681-686

Riebesell U, Zondervan I, Rost B, Tortell PD, Zeebe RE, Morel FMM (2000) Reduced calcification of marine plankton in response to increased atmospheric $\mathrm{CO}_{2}$. Nature 407:364-367

> Ries JB, Cohen AL, McCorkle DC (2009) Marine calcifiers exhibit mixed responses to $\mathrm{CO}_{2}$-induced ocean acidification. Geology 37:1131-1134

Sabine CL, Feely RA, Gruber N, Key RM and others (2004) The oceanic sink for anthropogenic $\mathrm{CO}_{2}$. Science 305: 367-371

Sato-Okoshi W, Okoshi K, Sasaki H, Akiha F (2010) Shell structure characteristics of pelagic and benthic molluscs from Antarctic waters. Polar Sci 4:257-261

> Steinacher M, Joos F, Frölicher TL, Plattner G, Doney SC (2009) Imminent ocean acidification in the Arctic projected with the NCAR global coupled carbon cycleclimate model. Biogeosciences 6:515-533

Yamamoto-Kawai M, McLaughlin FA, Carmack EC, Nishino S, Shimada K (2009) Aragonite undersaturation in the Arctic Ocean: effects of ocean acidification and sea ice melt. Science 326:1098-1100

Submitted: May 30, 2011; Accepted: February 29, 2012 Proofs received from author(s): May 30, 2012 